\title{
Variation of soil bacterial communities along a chronosequence of Eucalyptus plantation
}

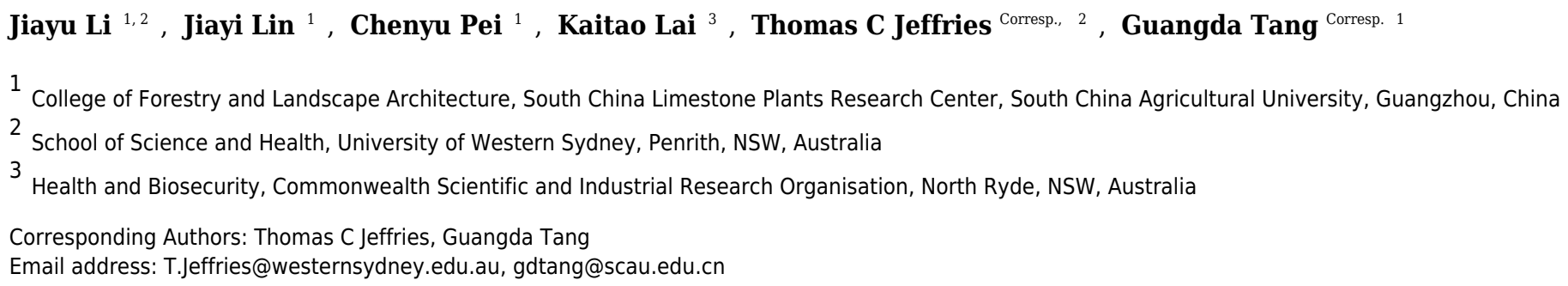

Eucalyptus is harvested for wood and fiber production in many tropical and sub-tropical habitats globally. Plantation has been controversial because of its influence on the surrounding environment however the influence of massive Eucalyptus planting on soil microbial communities is unclear. Here we applied high-throughput sequencing of the $16 \mathrm{~S}$ rRNA gene to assess the microbial community composition and diversity of planting chronosequences, involving two, five and ten years of Eucalyptus plantation, comparing to that of secondary-forest in South China. We found that significant changes in the composition of soil bacteria occurred when the forests were converted from secondaryforest to Eucalyptus. The bacterial community structure was clearly distinct from control and five year samples after Eucalyptus was grown for two and ten years, highlighting the influence of this plantation on local soil microbial communities. These groupings indicated a cycle of impact (two- and ten-year plantations) and low impact (five-year plantations) in this chronosequence of Eucalyptus plantation. Community patterns were underpinned by shifts in soil properties such as pH and phosphorus concentration. Concurrently, key soil taxonomic groups such as Actinobacteria showed abundance shifts, increasing in impacted plantations and decreasing in low impacted samples. Shifts in taxonomy were reflected in a shift in metabolic potential, including pathways for nutrient cycles such as carbon fixation, which changed in abundance over time following Eucalyptus plantation. Combined these results confirm that Eucalyptus plantation can change the community structure and diversity of soil microorganisms with strong implications for land-management and maintaining the health of these ecosystems. 
1 Variation of soil bacterial communities along a chronosequence of Eucalyptus plantation

\author{
Jiayu Li ${ }^{1,2}$, Jiayi Lin ${ }^{1}$, Chenyu Pei ${ }^{1}$, Kaitao Lai ${ }^{3}$, Thomas C Jeffries ${ }^{2 *}$, Guangda Tang ${ }^{1 *}$
}

1, College of Forestry and Landscape Architecture, South China Limestone Plants Research Center, South China Agricultural University, Guangzhou, China;

2, School of Science and Health, Western Sydney University, Penrith, NSW, Australia;

3, Health and Biosecurity, Commonwealth Scientific and Industrial Research Organisation, North Ryde, NSW 2113, Australia.

* co-contributing, author for correspondence:

Tang GD gdtang@scau.edu.cn;

Jeffries TC T.Jeffries@,westernsydney.edu.au

ABSTRACT: Eucalyptus is harvested for wood and fiber production in many tropical and sub-tropical habitats globally. Plantation has been controversial because of its influence on the surrounding environment however the influence of massive Eucalyptus planting on soil microbial communities is unclear. Here we applied highthroughput sequencing of the 16S rRNA gene to assess the microbial community composition and diversity of planting chronosequences, involving two, five and ten years of Eucalyptus plantation, comparing to that of secondary-forest in South China. We found that significant changes in the composition of soil bacteria occurred when the forests were converted from secondary-forest to Eucalyptus. The bacterial community structure was clearly distinct from control and five year samples after Eucalyptus was grown for two and ten years, highlighting the influence of this plantation on local soil microbial communities. These groupings indicated a cycle of impact (two- and ten- year plantations) and low impact (five-year plantations) in this chronosequence of Eucalyptus plantation. Community patterns were underpinned by shifts in soil properties such as $\mathrm{pH}$ and phosphorus concentration. Concurrently, key soil taxonomic groups such as Actinobacteria showed abundance shifts, increasing in impacted plantations and decreasing in low impacted samples. Shifts in taxonomy were reflected in a shift in metabolic potential, including pathways for nutrient cycles such as carbon fixation, which changed in abundance over time following Eucalyptus plantation. Combined these results confirm that Eucalyptus plantation can change the community structure and diversity of soil microorganisms with strong implications for land-management and maintaining the health of these ecosystems.

\title{
Introduction
}

Eucalyptus (Eucalyptus spp.), a Myrtaceae species that is native to Australia, is now extensively planted at the global scale because of its fast-growth and strong adaptability to the local environment. It occupies approximately 20 million hectares within the tropical artificial forests 
34 (Cook et al., 2016), while in China there are nearly 3.7 million ha of plantation, making the country 35 the second largest Eucalyptus plantation area (Versini et al., 2014; Zhang et al., 2016). Accompanying notable economic benefits(Ahmed, 1989), long-term Eucalyptus plantation, however, could induce some severe ecological impacts involving soil degradation and understory diversity loss due to allelopathy (Zhang \& Fu, 2009; Yang et al., 2017; Fang et al., 2009). Soil degradation via allelopathy likely impacts soil microbial diversity at the community level due to inhibition of key microbial taxa (Bertin et al., 2003).

In terrestrial ecosystems, soil microorganisms play crucial roles in ecological processes including pedogenesis, organic matter decomposition and nutrient cycling (Hu et al., 2015; Zeng et al., 2017; Hu et al., 2014). Soil bacteria are the most abundant and functionally diverse microbial taxa that drive processes which mediate soil quality and decompose organic substances (He et al., 2009), and the composition and diversity of soil bacterial communities are sensitive to environmental factors like soil characteristics and vegetation type (Huang et al., 2008; Leecruz et al., 2013). Plant productivity, diversity and community composition are driven directly or indirectly by the strong interdependence between plants and soil microbes, whereby a series of microbial metabolic activities that liberate available nutrients or other compounds can then be acquired by plants (Heijden et al., 2008). Conversely, soil bacterial and fungal communities have been shown to be affected by Eucalyptus plantations using PLFA (phospholipid fatty acid) analysis since the community structure was impacted significantly with the variation of planting age (Chen et al., 2013; Cao et al., 2010; Wu et al., 2013). This is contradictory to other studies reported which demonstrate that Eucalyptus plantations reduced microbial biomass, soil organic carbon and nitrogen concentrations during continuous planting (Behera \& Sahani, 2003; Cortez et al., 2014).Another relevant study of secondary tropical forest (SF) converted into Eucalyptus plantations (EP) using high-throughput sequencing techniques revealed a significant difference between SF and EP samples in bacterial composition and diversity (Lan et al., 2017). Given that these tools can elucidate the impact of artificial planting, especially on the surrounding soil ecosystem affected by the functioning of microbial communities if impacted (Zhang et al., 2017; Zheng et al., 2017; Zhou et al., 2017; Lin et al., 2017), their application will better define the response of soil microbial community diversity and function to land use shift and long-term Eucalyptus plantation, which remains obscure.

In this study, we used high-throughput sequencing of the 16S rRNA gene to assess soil bacterial diversity and community composition and shifts in functional potential along a chronosequence of Eucalyptus plantations (2 years, 5 years and 10 years; a nearby secondary- 
67 forest was simultaneously investigated as control). We highlighted the following questions: (a) how soil bacterial diversity and community composition varied between different Eucalyptus plantation stages and the secondary-forest. (b) what are the main factors driving the structure and composition of bacterial communities along the plantation chronosequences and (c) how functional profiles of bacterial communities involving nutrient cycling, metabolism and degradation shifted by Eucalyptus plantation at different growing stages.

\section{Materials \& Methods}

\section{Site information and soil sampling}

Soil samples were collected from Eucalyptus plantations in the Zhenlong Town of Huizhou City, Guangdong Province, South China (22 $96^{\prime}$ N, 114³6' E) (Fig. 1) on June $8^{\text {th }}$, 2017. The climate of this region belongs to the subtropical monsoon climate with an average annual precipitation of $2,000 \mathrm{~mm}$, mainly from April to September, and the mean annual temperature was $22^{\circ} \mathrm{C}$. The current Eucalyptus forests have been planted for many years as a substitution after cutting down all trees in previous secondary-forest.An adjacent secondary-forest which was defined as forest lands formed naturally under the impact of human activities (Corlett, 1994), was investigated and sampled as the control.

According to the space for time substitution procedure (Zheng et al., 2017), we selected four forests including 2 years (2YR), 5 years (5YR) and 10 years (10YR) Eucalyptus plantations and the secondary-forest. In each forest, three $20 \times 20 \mathrm{~m}^{2}$ plots were established in random locations and soil samples were collected. Within each plot, the detritus and litter were swept away, and five soil cores of $0 \sim 15 \mathrm{~cm}$ depth was collected, pooled and mixed into a composite sample. A total of 12 composite soil samples were collected from every different Eucalyptus plantation stages and secondary-forest on a similar gradient and altitude approximately . Composite soil samples were stored with ice bags and transported to the laboratory as soon as possible for downstream treatments. All the samples were sieved through $2 \mathrm{~mm}$ mesh and divided into two groups, with one group stored in $4^{\circ} \mathrm{C}$ for soil properties measurement, and the other group frozen in $-80^{\circ} \mathrm{C}$ for soil community DNA extraction.

\section{Measurement on soil physicochemical properties}

The soil $\mathrm{pH}$ was determined by a $\mathrm{pH}$ monitor with a soil to water ratio of 1:2.5. The soil organic carbon (SOC) and total nitrogen (TN) were measured in $\mathrm{K}_{2} \mathrm{Cr}_{2} \mathrm{O}_{7}$ oxidation and the Kjeldahl method. Total phosphorus (TP) and total potassium (TK) were measured with the alum molybdate yellow colorimetric method and the atomic absorption spectrophotometry. Available nitrogen (AN) and available potassium (AK) were quantified using the alkali-hydrolyzed diffusing method 
100 and flame photometer, respectively. Available phosphorus (AP) was immersed with $0.5 \mathrm{~mol} / \mathrm{L}$ $101 \mathrm{NaHCO}_{3}$, and then measured by Mo-Sb colorimetric method. Soil $\mathrm{NH}_{4}{ }^{+}$and $\mathrm{NO}_{3}{ }^{-}$were assayed 102 with a flow analyzer (AA3, SEAL analytical, Germany).

\section{Soil community DNA extraction and high-throughput sequencing}

104 The total genomic DNA of soil was extracted from $0.2 \mathrm{~g}$ of each sample using the Power Soil 105 DNA Isolation kit (MoBio Industries, Carlsbad, CA, USA) following the manufacturer's 106 instructions. Quality of the extracted DNA was determined with a NanoVue Plus 107 spectrophotometer (GE, New Jersey, USA) and 1\% agarose gel electrophoresis. The V3-V4 hyper108 variable region of the $16 \mathrm{~S}$ rRNA gene was amplified using primers 338F (5'ACTCCTACGGGAGGCAGCAG-3') and 806R (5'-GGACTACHVGGGTWTCTAAT-3'). The following PCR reaction program consists of an initial denaturation at $95^{\circ} \mathrm{C}$ for $3 \mathrm{~min}, 28$ cycles of $95^{\circ} \mathrm{C}$ for $30 \mathrm{~s}, 55^{\circ} \mathrm{C}$ for $30 \mathrm{~s}, 72^{\circ} \mathrm{C}$ for $45 \mathrm{~s}$, then $72^{\circ} \mathrm{C}$ for $10 \mathrm{~min}$ and $10^{\circ} \mathrm{C}$ until halted manually. PCR products were pooled with an equimolar concentration and sequenced with length of $300 \mathrm{bp}$ using a MiSeq sequencer and TruSeq chemistry (Illumina, San Diego, CA, USA) at Shanghai Majorbio Bio-pharm Technology Co., Ltd.

\section{Bioinformatics analysis}

After sequencing, the primary analysis of raw FASTQ data was processed with the QIIME2 pipeline (version 2017.10; http://qiime2.org/)(Caporaso et al., 2010). Briefly, DADA2 (Callahan et al., 2016) was used for error-correction, quality filtering, chimera removal and sequence variant calling of the Illumina amplicon sequences, with reads truncated at $270 \mathrm{bp}$, corresponding to a quality score $>20$. Resultant feature sequences (sOTUs) were summarized and then annotated using an RDP classifier (Cole et al., 2009) pre-trained to the full-length Greengenes database (version Aug,2013)(DeSantis et al., 2006). sOTU can be used interchangeably with amplicon sequence variants that it refers to sequences that differ by $>1$ nucleotide. The predictive functional categories of bacterial community were annotated through Phylogenetic Investigation of Communities by Reconstruction of Unobserved States (PICRUSt) and generated metabolic pathways depending on KEGG Orthologs at level 3 after importing the normalized sOTU table (Langille et al., 2013). This sOTU table was generated in QIIME2 by performing closed reference clustering of sOTU sequence variants against the Greengenes database (version Aug,2013, 99\%)(DeSantis et al., 2006) using VSEARCH(Rognes et al., 2016). The raw data have been deposited with the European Nucleotide Archive database (http://www.ebi.ac.uk/ena) under accession code ERP109013. 


\section{Statistical analysis}

133 The estimated alpha diversity including number of sOTUs, Shannon and Chaol indices were 134 calculated within QIIME2 with a resampling depth of 27,838 sequences per sample to ensure even 135 sampling depth with statistical significance determined using Kruskal-Wallis tests. Using rarefied 136 sOTU table, the relative correlation between biotic and environmental similarity matrices was 137 calculated using Mantel-tests within QIIME2 using the vegan package of R(Oksanen J et al., 2007) 138 to elucidate which variables most influenced microbial community structure. Principal coordinates 139 analysis (PCoA) was carried out based on the weighted Unifrac distance (Lozupone et al., 140 2011)between samples in QIIME2 with the significance of sample groupings determined using 141 Analysis of Similarities (ANOSIM)(Clarke, 1993). Environmental variables found to have the 142 most significant influence using the Mantel-tests were mapped as colour gradients to PCoA 143 ordinations. According to the results of mantel test, we choose $\mathrm{pH}(P=0.025, r=0.328)$, $144 \mathrm{TN}(P=0.048, r=0.297), \operatorname{TP}(P=0.041, r=0.303)$ and $\operatorname{AP}(P=0.104, r=0.22)$ to assess the association 145 between bacterial community structure and soil environmental factors by canonical 146 correspondence analysis (CCA) using the vegan package in R.

147 Differentially abundant features were determined by Linear discriminant analysis Effect Size 148 (LEfSe) in biobakery(Segata et al., 2011). Additionally, one-way analysis of variance (ANOVA) 149 was applied to evaluate significant differences based on Least Significant Difference (LSD) 150 method in species composition and soil chemistry among samples, with a least significant 151 difference $(P<0.05)$ using SPSS 19.0 (IBM Corporation, Armonk, NY, USA).

\section{Results}

\section{Soil physicochemical characteristics}

154 Soil physicochemical characteristics potentially affected by Eucalyptus plantations are shown in 155 Table 1. The soil $\mathrm{pH}$ and SOC in the secondary forest and 5YR Eucalyptus soil were higher 156 $(\mathrm{p}<0.01)$ than 2YR and 10YR Eucalyptus soils. By contrast, available phosphorus (AP) of 2YR, 10YR Eucalyptus soil were higher than 5YR and secondary-forest samples $(\mathrm{p}<0.05)$, and TP increased significantly ( $<<0.01)$ with the time of Eucalyptus planting, while reached a stable value between 5YR and 10YR soils. The content of TK decreased with plantation age of Eucalyptus, but recovered higher than origin in the later plantation stage. The $\mathrm{NH}_{4}{ }^{+}$content was changed significantly $(\mathrm{p}<0.01)$ comparing the different age of Eucalyptus soil and secondary forest, which showed the lowest value in 10YR soils. But there were no significant changes in soil TN, AN and AK contents among the secondary forest and Eucalyptus plantations.

\section{Diversity of soil bacterial community}


In total, 427687 high-quality sequences were obtained from 12 soil samples in three different age stages of Eucalyptus plantations and secondary-forest with reads quality trimmed to $270 \mathrm{bp}$. subsequent reads were normalized to 27838 sequences with rarefaction curves (Fig. S1) determining that this depth was sufficient to describe the sample diversity.

The numbers of observed sOTUs were 648,642,684,643 in 2YR, 5YR, 10YR Eucalyptus plantation and secondary-forest respectively (Fig. S1). The estimated Shannon indexes did not significantly differ among different ages of Eucalyptus plantation and secondary forest (Fig. S2). The Chaol index increased along the Eucalyptus plantations however this trend was not statistically significant (Fig. S2).

\section{Structure and composition of bacterial communities}

When using weighted Unifrac Samples formed distinct clusters in the PCoA plot (Fig.1) based on planting year, one cluster consisting of samples from 2 year and 10 year plantations and one with samples from 5 year and SF plantations (Fig. 2). This however was primarily explained by axis $2(18.69 \%)$ with grouping being less clear along the primary axis, which explained $47.38 \%$ of variation. Interestingly, when we used unweighted Unifrac samples grouped more clearly by plantation year indicating that diversity is to some degree partitioned by age, however this is primarily being realized in less abundant taxa (Fig. S3). Further statistical analysis revealed that overall, plantation year did not significantly explain beta-diversity patterns (anosim result, $P=0.073$ ), however the difference between the $2 \mathrm{YR} / 10 \mathrm{YR}$ cluster and the $5 \mathrm{YR} / \mathrm{SF}$ cluster was significant $(P=0.014)$. As the 2 YR and 10YR samples strongly differ from the control nonplantation SF samples, we have termed this cluster "impacted". However, as the community in the 5YR samples groups with the control SF plantation we have termed this group "low impacted" (refer to Discussion). Mantel tests showed that $\mathrm{pH}$ and AP were primary environmental drivers of beta-diversity patterns (Table 2 ) and clearly differ between the $5 \mathrm{YR} / \mathrm{SF}$ low impacted cluster and 2YR/10YR impacted cluster (Fig. 3).

Sequences variants were classified into 29 phyla, 85 classes, 150 orders, 236 families and 344 genera, including some unclassified or no rank species. The dominant phyla included Proteobacteria, Actinobacteria, Acidobacteria, Chloroflexi, Planctomycetes, WPS-2 and Verrucomicrobia (Fig. 4), whose relative abundance were above 2\%. The Proteobacteria had the highest abundance, especially in secondary forest, but decreased with the increased years of Eucalyptus plantation, accounting for $44.22 \%, 41.3 \%, 39.75 \%$ and $37.34 \%$ respectively (Fig. 4) however this difference was not statistically significant (ANOVA P >0.05, Table 3). The relative abundance of Actinobacteria increased significantly (ANOVA P $<0.05$ ) in $2 \mathrm{YR}$ 
Eucalyptus plantations, but recovered to the SF abundance in later plantation years (Fig. 4, Table 3). WPS-2 climbed significantly in $2 \mathrm{YR}$ and $10 \mathrm{YR}$ but was detected no significant variation in 5YR and secondary-forest (Fig. 4, Table 3). In comparison with the secondary-forest soil, the relative abundance of Cyanobacteria, TM6 and Tenericutes in Eucalyptus forest showed a significant decrease (ANOVA P < 0.05), but not with the increasing year of Eucalyptus plantation relative to SF. However, the Gemmatimonadetes and AD3 were significantly higher in Eucalyptus plantation than that in secondary forest (ANOVA P <0.05, Fig. 4, Table 3).

At the genus level (Table S1, approximately 50\% were listed), the dominant genera in both Eucalyptus plantation soil and secondary forest were Rhodoplanes, and lineages within the order Actinomycetales and family Rhodospirillaceae, however these showed no significant variation between samples. Abundant genera $(>2 \%)$ displaying significant differences in abundance between samples based on one-way ANOVA $(P<0.05)$ were listed in Table S1. Candidatus Koribacter increased in abundance in the 10YR(1.94\%) sample relative to SF, however did not significantly change in the three treatment groups. The relative abundance of Bradyrhizobium showed a significant drop in the 10YR(1.86\%) sample, but was consistent across early stages of Eucalyptus plantation. Additionally, the Conexibacter in $5 \mathrm{YR}(0.14 \%)$ decreased significantly compared with the $2 \mathrm{YR}(0.48 \%)$ sample, although was not significantly different between Eucalyptus samples and SF. By contrast, Skermanella in the 5YR(0.13\%) soil decreased relative to $\mathrm{SF}(1.21 \%)$, but recovered in $10 \mathrm{YR}(0.53 \%)$ samples. Azospirillum increased significantly in 2YR Eucalyptus samples (0.98\%), while relative abundance decreased back to the original level in 5 and 10 year plantations.

Overall 16 taxonomic groups were overrepresented in samples forming the impacted cluster and 19 taxonomic groups were overrepresented in the low impacted cluster samples (Fig. 5) as determined by LEfSe LDA scores (Fig. S4). In particular, taxa at different phylogenetic levels within the Actinobacteria phylum were significantly different in abundance between the impacted and low impacted clusters (Fig. 5). These included the Thermoleophilia order, Acidimicrobiia order, Solirubrobacterales class, Acidimicrobiales class, Pseudonocardiaceae family and Nocardiaceae family. Moreover, At the genus level, Bradyrhizobium were found to predominate in soils of low impacted cluster, as well as Myxococcales at the order level. The plots of features above with statistically significant differences between clusters were put into supplementary materials (Fig. S5;Fig. S6;Fig. S7).

\section{Relationships between bacterial community and soil characteristics}

CCA (Canonical Correlation Analysis) was carried out to identify the main soil characteristics 
231

232

233

234

235

236

237

238

239

240

241

242

243

244

245

246

247

248

249

250

251

252

253

254

255

256

257

258

259

260

261

262

263

driving community patterns in Eucalyptus plantation and secondary forest soil samples. According to the Mantel test results (Table 2), four soil properties demonstrated a strong relationship to beta diversity patterns and are included as vectors in the CCA analysis (Fig. 6). The first two axes of the CCA explain $31.14 \%$ and $26.58 \%$, of the variability respectively (Fig. 6). The result showed that $\mathrm{pH}$ was positively associated with $5 \mathrm{YR}$ and SF soil samples (the low impacted cluster), but negatively associated with $2 \mathrm{YR}$ and $10 \mathrm{YR}$ and explained $89.66 \%$ of CCA1. In addition, likewise on CCA1, TP and AP were positively correlated with the 2YR and 10YR soils (impacted cluster), while contrary to the $5 \mathrm{YR}$ and SF samples.

\section{Function prediction of bacteria}

The potential metabolic functions of soil taxa were predicted using PICRUSt, a software package that uses the genomic composition of organisms closely related to the $16 \mathrm{~S}$ rDNA composition of the sampled community and the predicted metagenome correlated to an actual metagenome with a Spearman's R of 0.81 for soil microbial communities (Langille et al., 2013). Related genes collapsed into KEGG pathways at level 3 of the KEGG hierarchy with a mean NSTI score of 0.12 and varied significantly between clusters of Eucalyptus plantation with $20 \%$ of pathways having a corrected P-value < 0.05 (Table S2).

In particular nitrogen metabolism, amino acid metabolism and energy metabolism, degradation in bisphenol, chlorocyclohexane and chlorobenzene, chloroalkane and chloroalkene decreased significantly in the impacted cluster (Fig. 7, Table S2). Additionally, glycoysis and TCA cycle in impacted increased significantly than that in low impacted samples.

\section{Discussion}

Overall what makes this study site, a model system for the influence of Eucalyptus plantation, interesting is that during a chronosequence of Eucalyptus plantation, composition and function of soil bacteria community were shifted in impacted years but lower impact was observed in the fiveyear plantation. Furthermore, soil properties were altered significantly, which were treated as a main factor driving community variation.

\section{Soil properties}

Key soil properties such as $\mathrm{pH}$, SOC and phosphorus concentration (TP and AP) were altered between secondary forest and Eucalyptus plantations or shifted with plantation time indicating the influence of Eucalyptus on resident soil microbial communities. Soil $\mathrm{pH}$ as an indicator of soil condition is affected easily by understory vegetation and plantation. Eucalyptus plantations generally may lead to soil acidification when converted from original vegetation, as observed after ten years(Rhoades \& Binkley, 1996; Sicardi et al., 2004). In our study, the lower pH values were 
264 shown in 2YR and 10YR Eucalyptus soil compared with secondary-forest, which may be a

265

266

267

268

269

270

271

272

273

274

275

276

277

278

279

280

281

282

283

284

285

286

287

288

289

290

291

292

293

294

295

296

consequence of the accelerated extraction of cations and of compounds released from decaying leaf litter (Soumare et al., 2016). Consistent with our results, the amount of soil SOC has been shown to decrease after planting Eucalyptus (Behera \& Sahani, 2003; Cook et al., 2016; Zhang et al., 2015) but also to increase in some conditions (Zhang et al., 2012). Infertile soil organic matter may decrease soil structural stability leading to erosion (Behera \& Sahani, 2003). The investigation of soil properties indicated that soil SOC content in 2YR and 10YR was less than that in secondaryforest. Nevertheless, the highest soil SOC value in 5YR Eucalyptus plantation may be caused by low decomposition rates of microbial communities (Zheng et al., 2017). Soil SOC and other soil nutrients differed between Eucalyptus soil and original forest, such as TP and AP, or stabilized under certain conditions (TP), probably partly arising from processes such as litter fall decomposition, leaching and mineralization (Falkiner \& Smith, 1997; Jaiyeoba, 1998; Laclaua et al., 2003). Phosphorus concentrations may exhibit an increase during the process of decomposition of leaf litter (Ribeiro et al., 2002; Han et al., 2011).

\section{Community diversity patterns}

Several of the above variables were identified as key drivers in determining microbial community structure and underpinning the clustering of samples into groups determined by plantation age. $\mathrm{pH}$ has been identified as an important variable in determining microbial diversity patterns on a number of scales (Fierer \& Jackson, 2006) and is a factor in determining plantation soil community composition (Zhou et al., 2017). Nutrient concentration (P,N) is also generally a major driver of microbial diversity patterns (Leff et al., 2015) including in forest habitats (Liu et al., 2012) and Eucalyptus plantations (Lan et al., 2017) and our results are consistent with this.

The low explanatory power of CCA1 and CCA2 may suggest that some relative factors were not measured and that these also play a role in determining community diversity patterns.

Overall, our beta-diversity patterns showed a cycle of impact (2YR/10YR), which was defined as a strong dissimilarity to the native soil conditions in the control SF, and low impacted (5YR), where soil microbial diversity patterns resolved to a high-degree of similarity to control SF samples. This was not stable over time as samples were low impacted after 5 years then displayed community profiles indicative of higher impact after 10 years. The lower impact of soil communities has been observed following Eucalyptus plantations recently (Chen et al., 2013) however short-term fluctuations in microbial diversity are not well described in plantation systems. The mechanism for this is potentially driven by patterns mediated by a lowering of soil $\mathrm{pH}$ and increases in nutrient concentration as a consequence of leaf litter and tree-root inputs, such as 
297 allelochemicals, as described above (Khan et al., 1999; Mitchell et al., 2012) in the impacted samples. Indeed, following experimental addition of Eucalyptus leaves to control SF soil nutrient concentrations increased however this experiment was only conducted on a short time-scale $(<6$ months, Table S3). The 5 years samples, being defined by a higher $\mathrm{pH}$ and lower nutrient concentrations, were potentially less influenced by inputs derived from plant material. Collectively this highlights the importance of managing leaf litter, tree harvesting and nutrient input in influencing soil chemical properties and microbial community composition and that microbial responses to plantation are not stable over time.

Alpha diversity of soil bacterial community in Eucalyptus plantations has been found to be higher than native forest environment (Silveira et al., 2006; Lan et al., 2017). However, we found no significant differences in bacterial alpha-diversity (species richness, diversity indices) between Eucalyptus and other forest sites even though there were alterations in the structure of soil bacterial community. Thus the above inputs drive shifts in relative abundance rather than presence absence of community members. This homogeneity of alpha-diversity has been observed in similar plantations (Kerfahi et al., 2016).

\section{Taxonomic composition shifts}

The most abundant phyla, Proteobacteria, Actinobacteria, Acidobacteria and Verrucomicrobia are well-represented in most forest soils (Ederson Da C Jesus et al., 2009; Fierer et al., 2007; Lan et al., 2017; Spain et al., 2009), and the distribution of dominant bacteria were stable after Eucalyptus plantation in our study. The dominance of Proteobacteria and Acidobacteria as generally observed in most of soils indicated low impact by land-use type(Rampelotto et al., 2013), which may explain the small degree of variation among treatments of both of these phyla. Acidobacteria have been reported in oligotrophic habitats with low nutrient concentrations, as well as a wide range of metabolic organic matter, low $\mathrm{C}$ mineralization rate and ability to tolerate fluctuations in adverse soil conditions (Aislabie \& Deslippe, 2013; Fierer et al., 2007; Rampelotto et al., 2013). Since Proteobacteria and Acidobabcteira could be considered as indicators of soil trophic level organisms (Smit et al., 2001; Zhang et al., 2017), the change from secondary-forest to Eucalyptus or stand age of Eucalyptus generated little effect on declining soil nutrition and metabolizing organic resource within the ten-year Eucalyptus plantation. Bacteria belonging to the phylum Actinobacteria were more dominant in impacted soils. Actinobacteria have been widely reported as playing critical roles in exuding antibiotics and secondary metabolites (Quirinoa et al., 2009; Lauber et al., 2013), and their increased abundance in impacted samples could have consequences on these processes. Degradation of SOC in soils could lead to the high level of 
330

331

332

333

334

335

336

337

338

339

340

341

342

343

344

345

346

347

348

349

350

351

352

353

354

355

356

357

358

359

360

361

362

Actinobacteria observed in impacted soils (2YR and 10YR), because of its higher ability to consume organic carbon pools and its copiotrophs lifestyle (Rampelotto et al., 2013; Zhang et al., 2017; He et al., 2012). Significant variation in the genus Bradyrhizobium between impacted and low impacted clusters illustrates the low ability of nitrogen-fixing in the Eucalyptus plantation (Silva et al., 2014). Likewise, Cyanobacteria was beneficial to nitrogen fixation and stabilized structure of soil by potentially binding particles in the terrestrial ecosystems (Eldridge \& Leys, 2003; Bowker et al., 2010). Hence, it was probable that soil in Eucalyptus plantations had less tolerance from wind and water erosion than in the secondary-forest. Accordingly, we suggest that land-use altered the soil structure and composition, contributing toward the productivity of soil. Combined, the shifts in abundance of taxonomic groups with functional significance highlight the impact of Eucalyptus plantation on local soils.

\section{Shifts in functional potential}

Taxonomic shifts between samples were reflected in the shifts in metabolic gene potential between the impacted and low impacted group, the result of which suggested a decrease in overrepresented functions in $2 \mathrm{YR}$ and 10YR impacted soils compared to low impacted potentially leading to an accumulation of metabolic products and nutrients. According to the gene families identified by PICRUSt analysis, we hypothesize that a decline in content of soil organic matter caused by breaking up macro-aggregates (Hoosbeek et al., 2006) likely triggered the increase of soil bacterial capacity to fix carbon when artificial plantation was sustained for a few years, which may partially explain microbes impacted by Eucalyptus plantings (Chen et al., 2013; Cortez et al., 2014). Overall, shifts in microbial function were evident between clusters indicating that $\mathrm{pH}$ and nutrient shifts as a consequence of plantation will likely impact microbial function in these soils.

\section{Conclusions}

Within a chronosequence of Eucalyptus plantation, soil microbial community structure shifted significantly in soils two and ten year's after plantation compared with secondary forest. Following five years of plantation, low impact was observed with the community showing a high-degree of similarity to control soils. The main factors which drove this partitioning were variation in $\mathrm{pH}$ and nutrient concentrations, such as phosphorus potentially resultant from leaf litter and plant inputs.

Microbial communities were not stable over the time-scale measured highlighting the need to understand microbial responses to plantation over varying time-scales to manage ecological outcomes for plantations, such as stable, healthy soil microbial communities.

\section{Acknowledgements}

We would like to thank Lin Huang and Hui Wang for their generous help in soil sampling. 


\section{References:}

Ahmed P. 1989. Eucalyptus in agroforestry: its effects on agricultural production and economics. Agroforestry Systems 8:31-38. DOI 10.1007/BF00159067

Aislabie J., Deslippe JR. 2013. Soil microbes and their contribution to soil services. Soil Microbial Diversity 19:143161. DOI 10.1016/j.scitotenv.2012.11.050

Behera N., Sahani U. 2003. Soil microbial biomass and activity in response to Eucalyptus plantation and natural regeneration on tropical soil. Forest Ecology and Management 174:1-11. DOI 10.1016/S0378-1127(02)00057-9

Bertin C, Yang X., Weston LA. 2003. The role of root exudates and allelochemicals in the rhizosphere. Plant and Soil 256:67-83.DOI 10.1023/A:1026290508166

Bowker MA., Maestre FT., Escolar C. 2010. Biological crusts as a model system for examining the biodiversity ecosystem function relationship in soils. Soil Biology and Biochemistry 42:405-417.DOI 10.1016/j.soilbio.2009.10.025

Callahan BJ., McMurdie PJ, Rosen MJ, Han AW, Johnson AJA, Holmes SP. 2016. DADA2: High-resolution sample inference from Illumina amplicon data. Nature Methods 13:581-583. DOI 10.1038/nmeth.3869

Cao YS., Fu SL., Zou XM., Cao HL., Shao YH., Zhou LX. 2010. Soil microbial community composition under Eucalyptus plantations of different age in subtropical China. European Journal of Soil Biology 46:128-135.DOI 10.1016/j.ejsobi.2009.12.006

Caporaso JG., Kuczynski J., Stombaugh J., Bittinger K., Bushman FD., Costello EK., Fierer N., Pena AG., Goodrich JK., Gordon JI., Huttley GA., Kelley ST., Knights D., Koenig JE., Ley RE., Lozupone CA., McDonald D., Muegge BD., Pirrung M., Reeder J., Sevinsky JR., Turnbaugh PJ., Walters WA., Widmann J., Yatsunenko T., Zaneveld J., Knight R. 2010. QIIME allows analysis of high-throughput community sequencing data. Nature Methods 7:335336.DOI 10.1038/nmeth.f.303

Chen FL., Zheng H., Zhang K., Ouyang ZY., Li HL. 2013. Soil microbial community structure and function responses to successive planting of Eucalyptus. Journal of Environmental Sciences 25:2102-2111.DOI 10.1016/S10010742(12)60319-2

Clarke KR. 1993. Non-parametric multivariate analyses of changes in community structure. Australian Journal of Ecology 18:117-143. DOI 10.1111/j.1442-9993.1993.tb00438.x

Cole JR., Wang Q., Cardenas E., Fish J., Chai B., Farris RJ., Kulam-Syed-Mohideen AS., McGarrell DM., Marsh T., Garrity GM., Tiedje JM. 2009. The Ribosomal Database Project: improved alignments and new tools for rRNA analysis. Nucleic Acids Research 37:D141-D145.DOI 10.1093/nar/gkn879

Cook RL., Binkley D., Stape JL. 2016. Eucalyptus plantation effects on soil carbon after 20years and three rotations in Brazil. Forest Ecology and Management 359:92-98.DOI 10.1016/j.foreco.2015.09.035

Corlett R. 1994. What is secondary forest. Journal of Tropical Ecology 10(3):445-447. DOI $10.1017 / \mathrm{S} 0266467400008129$

Cortez CT., Nunes, L., Rodrigues LB., Eisenhauer N., Araújo A. 2014. Soil microbial properties in Eucalyptus grandis plantations of different ages. Journal of Soil Science and Plant Nutrition 14:734-742. DOI 10.4067/S071895162014005000059

DeSantis TZ., Hugenholtz P., Larsen N., Rojas M., Brodie EL., Keller K., Huber T., Dalevi D., Hu P., Andersen GL. 2006. Greengenes, a Chimera-Checked 16S rRNA Gene Database and Workbench Compatible with ARB.Applied and Environmental Microbiology 72:5069-5072.DOI 10.1128/AEM.03006-05 
404

405

406

407

408

409

410

411

412

413

414

415

416

417

418

419

420

421

422

423

424

425

426

427

428

429

430

431

432

433

434

435

436

437

438

439

440

441

442

443

444

Ederson CJ, Terence LM, Tiedje JM. 2009. Changes in land use alter the structure of bacterial communities in Western Amazon soils. The ISME Journal 3:1004-1011.DOI 10.1038/ismej.2009.47

Eldridge DJ., Leys JF. 2003. Exploring some relationships between biological soil crusts, soil aggregation and wind erosion. Journal of Arid Environments 53:457-466.DOI 10.1006/jare.2002.1068

Fang BZ., Yu SX., Wang YF., Qiu X., Cai CX., Liu SP. 2009. Allelopathic effects of Eucalyptus urophylla on ten tree species in south China. Agroforestry Systems 76:401-408.DOI 10.1007/s10457-008-9184-8

Fierer N., Bradford MA., Jackson RB. 2007. Toward an ecological classification of soil bacteria. Ecology 88:13541364.DOI 10.1890/05-1839

Fierer N., Jackson RB. 2006. The diversity and biogeography of soil bacterial communities. PNAS 103:626-631.DOI 10.1073/pnas.0507535103

Han MY., Zhang LX., Fan CH., Liu LH., Zhang LS., Li BZ., Alva AK. 2011. Release of nitrogen, phosphorus, and potassium during the decomposition of apple (Malus domestica) leaf litter under different fertilization regimes in Loess Plateau, China. Soil Science and Plant Nutrition 57:549-557. DOI 10.1080/00380768.2011.593481

He JZ, Ge Y, Xu ZH, Chen CR. 2009. Linking soil bacterial diversity to ecosystem multifunctionality using backwardelimination boosted trees analysis. J Soils Sediments 9:547-554 DOI 10.1007/s11368-009-0120-y

He ZL., Piceno Y., Deng Y., Xu MY., Lu ZM., Desantis T., Andersen G., Hobbie SE., Reich PB., Zhou JZ. 2012. The phylogenetic composition and structure of soil microbial communities shifts in response to elevated carbon dioxide. ISME Journal 6:259-272. DOI 10.1038/ismej.2011.99

Hoosbeek MR., Vos JM., Bakker EJ., Scarascia-Mugnozza GE. 2006. Effects of free atmospheric CO2 enrichment (FACE), $\mathrm{N}$ fertilization and poplar genotype on the physical protection of carbon in the mineral soil of a polar plantation after five years. Biogeosciences 3:479-487.DOI 10.5194/bg-3-479-2006

Hu HW, Chen DL, He JZ. 2015. Microbial regulation of terrestrial nitrous oxide formation: understanding the biological pathways for prediction of emission rates. Fems Microbiology Reviews 39:729-749. DOI 10.1093/femsre/fuv021

Hu HW, Xu ZH, He JZ. 2014. Ammonia-Oxidizing Archaea Play a Predominant Role in Acid Soil Nitrification D.L. Sparks (Ed.). Advances in Agronomy 125:261-302. DOI 10.1016/B978-0-12-800137-0.00006-6

Huang ZQ., Xu ZH., Chen CR. 2008. Effect of mulching on labile soil organic matter pools, microbial community functional diversity and nitrogen transformations in two hardwood plantations of subtropical Australia. Applied Soil Ecology 40:229-239. DOI 10.1016/j.apsoil.2008.04.009

Jaiyeoba IA. 1998. Changes in soil properties related to conversion of savannah woodland into pine and eucalyptus plantations, Northern Nigeria. Land Degradation \& Development 9:207-215. DOI 10.1002/(SICI)1099145X(199805/06)9:3<207::AID-LDR258>3.0.CO;2-M

Kerfahi D., Tripathi BM., Dong K., Go R., Adams JM. 2016. Rainforest Conversion to Rubber Plantation May Not Result in Lower Soil Diversity of Bacteria, Fungi, and Nematodes. Microbial Ecology 72:359-371.DOI 10.1007/s00248-016-0790-0

Laclaua J., Rangerb J., Nzila JD, Bouillet J., Deleporte P. 2003. Nutrient cycling in a clonal stand of Eucalyptus and an adjacent savanna ecosystem in Congo 2. Chemical composition of soil solutions. Forest Ecology and Management 180:527-544. DOI 10.1016/S0378-1127(02)00645-X

Lan GY., Li YW., Wu ZX., Xie GS. 2017. Soil Bacterial Diversity Impacted by Conversion of Secondary Forest to Rubber or Eucalyptus Plantations: A Case Study of Hainan Island, South China. Forest Science 63:87-93. DOI 10.5849/forsci.16-012 
Langille MGI., Zaneveld J., Caporaso JG., McDonald D., Knights D., Reyes JA., Clemente JC., Burkepile DE., Thurber RLV., Knight R., Beiko RG., Huttenhower C. 2013. Predictive functional profiling of microbial communities using 16S rRNA marker gene sequences. Nature Biotechnology 31:814-821. DOI 10.1038/nbt.2676

Lauber C.L., Ramirez KS., Aanderud Z., Lennon J., Fierer N. 2013. Temporal variability in soil microbial communities across land-use types. Isme Journal Multidisciplinary Journal of Microbial Ecology 7:1641. DOI 10.1038/ismej.2013.50

Leecruz L., Edwards DP., Tripathi BM., Adams JM. 2013. Impact of logging and forest conversion to oil palm plantations on soil bacterial communities in Borneo.Applied and Environmental Microbiology 79:7290-7297. DOI 10.1128/AEM.02541-13

Leff JW., Jones SE., Prober SM., Barberán A., Borer ET., Firn J.L., Harpole WS., Hobbie SE., Hofmockel KS., Knops JMH., McCulley RL., Pierre KL, Risch AC., Seabloom EW., Schütz M., Steenbock C., Stevens CJ., Fierer N. 2015. Consistent responses of soil microbial communities to elevated nutrient inputs in grasslands across the globe. Proceedings of the National Academy of Sciences 112:10967-10972. DOI 10.1073/pnas.1508382112

Lin Y., Whitman WB., Coleman DC., Jien S., Chiu C. 2017. Cedar and bamboo plantations alter structure and diversity of the soil bacterial community from a hardwood forest in subtropical mountain. Applied Soil Ecology 112:28-33. DOI 10.1016/j.apsoil.2017.01.001

Lozupone C., Lladser ME., Knights D., Stombaugh J., Knight R. 2011. UniFrac: an effective distance metric for microbial community comparison. The ISME Journal 5:169-172. DOI 10.1038/ismej.2010.133

Oksanen J, Kindt R, Legendre P, O’Hara B, Stevens MHH. 2007. The vegan Package. Community ecology package 10:631-637.

Quirinoa BF., Pappasa G., Tagliaferroa A. 2009. Molecular phylogenetic diversity of bacteria associated with soil of the savanna-like Cerrado vegetation. Microbiology Research 164:59-70. DOI 10.1016/j.micres.2006.12.001

Rampelotto PH., Ferreira AS, Barboza ADM., Roesch LFW. 2013. Changes in Diversity, Abundance, and Structure of Soil Bacterial Communities in Brazilian Savanna Under Different Land Use Systems. Soil Microbiology 66:593607. DOI 10.1007/s00248-013-0235-y

Rhoades C., Binkley D. 1996. Factors influencing decline in soil pH in Hawaiian Eucalyptus and Albizia plantations. Forest Ecology and Management 80:47-56. DOI 10.1016/0378-1127(95)03646-6

Ribeiro C., Madeira M., Araújo MC. 2002. Decomposition and nutrient release from leaf litter of Eucalyptus globulus grown under different water and nutrient regimes. Forest Ecology and Management 171:31-41. DOI 10.1016/S03781127(02)00459-0

Rognes T., Flouri T., Nichols B., Quince C., Mahé F. 2016. VSEARCH: a versatile open source tool for metagenomics. PeerJ 4:e2584. DOI 10.7717/peerj.2584

Segata N., Izard J., Waldron L., Gevers D., Miropolsky L., Garrett W.S., Huttenhower C. 2011. Metagenomic biomarker discovery and explanation. Genome Biology 12:R60. DOI 10.1186/gb-2011-12-6-r60

Sicardi M., Garc1 a-Préchac F., Frioni L. 2004. Soil microbial indicators sensitive to land use conversion from pastures to commercial Eucalyptus grandis (Hill ex Maiden) plantations in Uruguay. Applied Soil Ecology 27:125133. DOI 10.1016/j.apsoil.2004.05.004

Silveira ÉLD., Pereira RM., Scaquitto DC., Pedrinho EAN. 2006. Bacterial diversity of soil under eucalyptus assessed by $16 \mathrm{~S}$ rDNA sequencing analysis. Pesq. agropec. bras., Brasilia 41:1507-1516. DOI 10.1590/S0100204X2006001000008

Silva MCS, Paula TA, Moreira BC, Carolino M, Cruz C, Bazzolli DMS, Silva CC, Kasuya MCM.. 2014. Nitrogen- 
486 Fixing Bacteria in Eucalyptusglobulus Plantations. PLoS One 9:e111313. DOI 10.1371/journal.pone.0111313

487 Smit E., Leeflang P., Gommans S., Broke J., Mil S, Wernars K. 2001. Diversity and Seasonal Fluctuations of the 488 Dominant Members of the Bacterial Soil Community in a Wheat Field as Determined by Cultivation and Molecular Methods. Applied and Environmental Microbiology 67:2284-2291. DOI 10.1128/AEM.67.5.2284-2291.2001 Soumare A., Sall SN., Sanon A. 2016. Changes in soil pH, polyphenol content and microbial community mediated by Eucalyptus camaldulensis. Applied Ecology and Environmental Research 14:1-19. DOI 10.15666/aeer/1403_001019 Spain AM., Krumholz LR., Elshahed MS. 2009. Abundance, composition, diversity and novelty of soil Proteobacteria. International Society for Microbial Ecology 3:992-1000. DOI 10.1038/ismej.2009.43 Heijden MGA, Bardgett RD., Straalen NM. 2008. The unseen majority: soil microbes as drivers of plant diversity and productivity in terrestrial ecosystems. Ecology Letters 11:296-310. DOI 10.1111/j.1461-0248.2007.01139.x Versini A., Mareschal L., Matsoumbou T., Zeller B., Ranger J., Laclau J. 2014. Effects of litter manipulation in a tropical Eucalyptus plantation on leaching of mineral nutrients, dissolved organic nitrogen and dissolved organic carbon. Geoderma 232-234:426-436. DOI 10.1016/j.geoderma.2014.05.018 Wu JP., Liu ZF., Sun YX., Zhou LX. 2013. Introduced Eucalyptus Urophylla plantations change the composition of the soil microbial community in subtropical. Land Degradation and Development 24:400-406. DOI 10.1002/1dr.2161 Yang XB., Li DH., McGrouther K., Long WX., Li YL., Chen YK., Lv XB., Niazi NK., Song ZL, Wang HL. 2017. Effect of Eucalyptus forests on understory vegetation and soil quality. Journal of Soils and Sediments 17:2383-2389. DOI 10.1007/s11368-016-1431-4

Zeng QC., An SS., Liu Y. 2017. Soil bacterial community response to vegetation succession after fencing in the grassland of China. Science of the Total Environment 609:2-10.DOI 10.1016/j.scitotenv.2017.07.102 Zhang CL., Li XW., Chen YQ., Zhao J., Wan SZ., Lin YB., Fu SL. 2016. Effects of Eucalyptus litter and roots on the establishment of native tree species in Eucalyptus plantations in South China. Forest Ecology and Management 375:76-83. DOI 10.1016/j.foreco.2016.05.013

Zhang CL., Fu SL. 2009. Allelopathic effects of eucalyptus and the establishment of mixed stands of eucalyptus and native species. Forest Ecology and Management 258:1391-1396. DOI 10.1016/j.foreco.2009.06.045

Zhang DJ., Zhang J., Yang WQ., Wu FZ. 2012. Effects of afforestation with Eucalyptus grandis on soil physicochemical and microbiological properties. Soil Research 50:167-176. DOI 10.1071/SR11104

Zhang K., Zheng H., Chen FL., Ouyang ZY., Wang Y, Wu YF, Lan J, Fu M, Xiang XW. 2015. Changes in soil quality after converting Pinus to Eucalyptus plantations in southern China. Solid Earth 6:115-123. DOI 10.5194/se-6-1152015

Zhang WW., Lu ZT., Yang K., Zhu JJ. 2017. Impacts of conversion from secondary forests to larch plantations on the structure and function of microbial communities. Applied Soil Ecology 111:73-83. DOI 10.1016/j.apsoil.2016.11.019 Zheng JF., Chen JH., Pan GX., Wang GM., Liu XY., Zhang XH., Li LQ., Bian RJ., Cheng K., Zheng JW. 2017. A long-term hybrid poplar plantation on cropland reduces soil organic carbon mineralization and shifts microbial community abundance and composition. Applied Soil Ecology 111:94-104. DOI 10.1016/j.apsoil.2016.11.017

Zhou XQ., Guo ZY., Chen CR., Jia ZJ. 2017. Soil microbial community structure and diversity are largely influenced by soil $\mathrm{pH}$ and nutrient quality in 78-year-old tree plantations. Biogeosciences 14:2101-2111. DOI 10.5194/bg-142101-2017

Zhou YJ., Li JH., Ross FC., Wang HF. 2017. Variation of Soil Bacterial Communities in a Chronosequence of Rubber Tree (Hevea brasiliensis) Plantations. Frontiers in Plant Science 8:849. DOI 10.3389/fpls.2017.00849 
Figure 1

Sampling design and position in the Zhenlong Town of Huizhou City, Guangdong Province, South China $\left(22^{\circ} 96^{\prime} \mathrm{N}, 114^{\circ} 36^{\prime} \mathrm{E}\right)$.

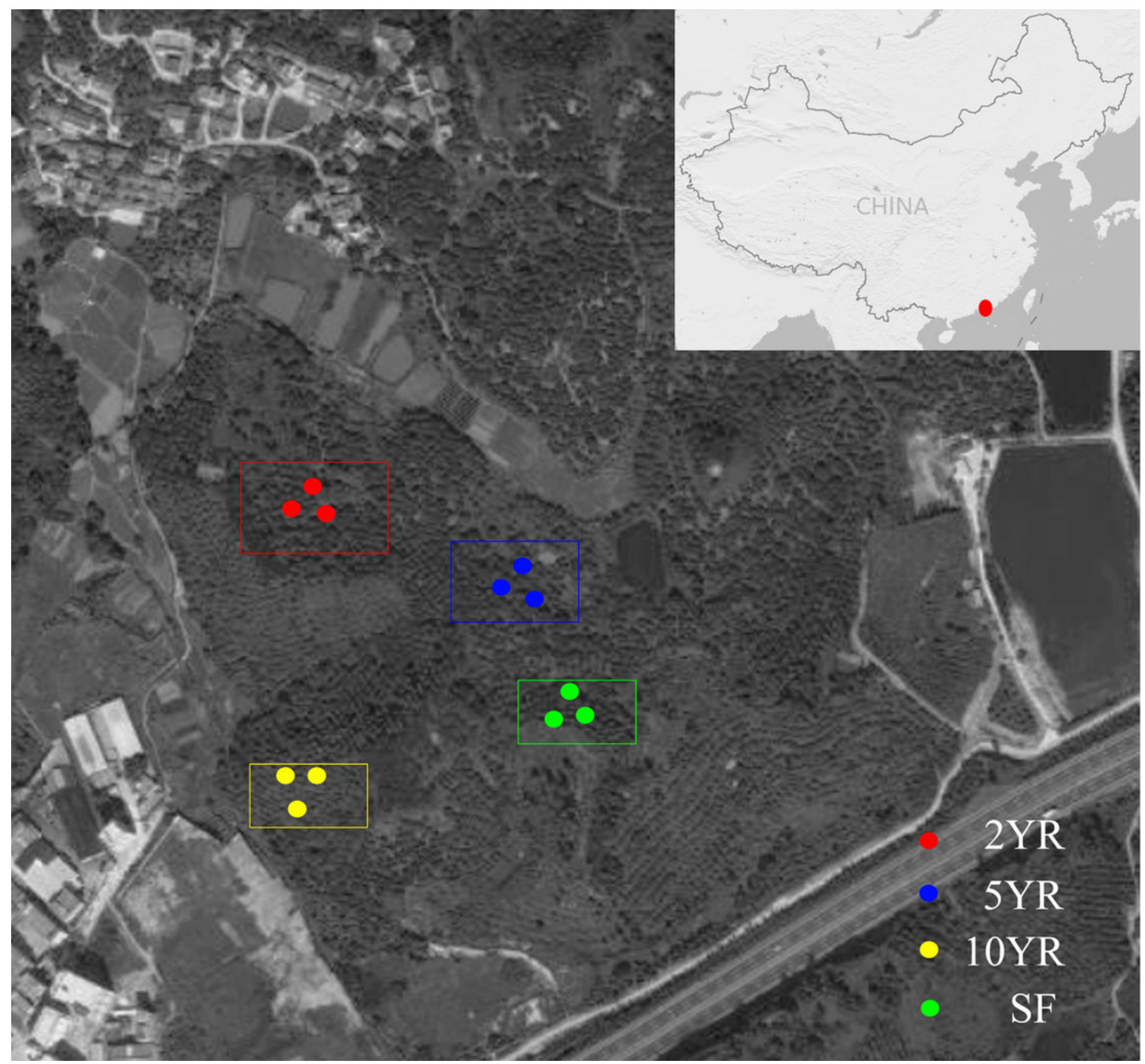


Figure 2

Principal coordinates analysis of bacterial community composition (weighted UniFrac dissimilarity) in Eucalyptus plantations and secondary forest soil

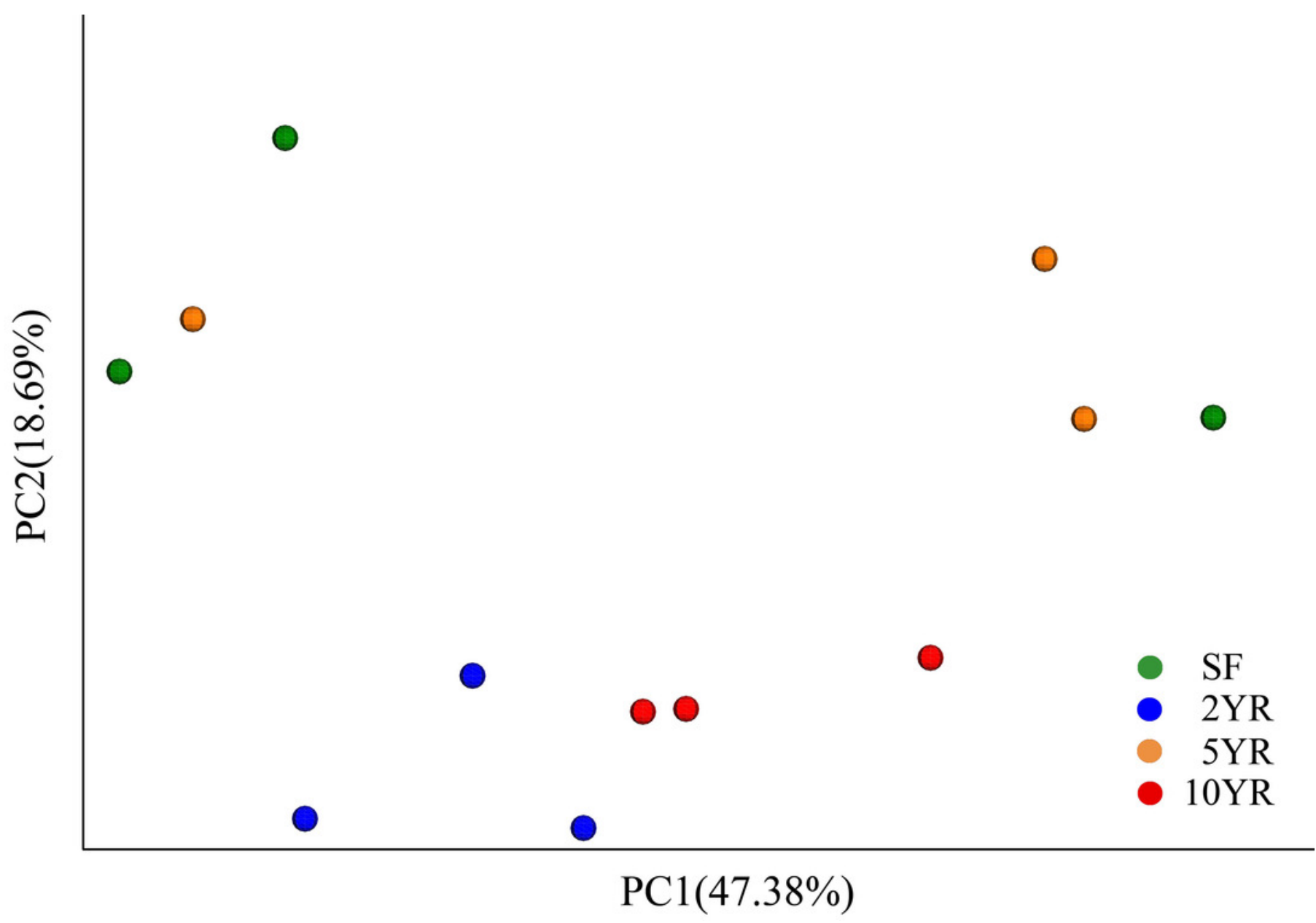


Figure 3

PCoA with color gradients mapped to a) $\mathrm{pH}$ and b) AP. Circles denote clusters defined as impacted and low impacted.
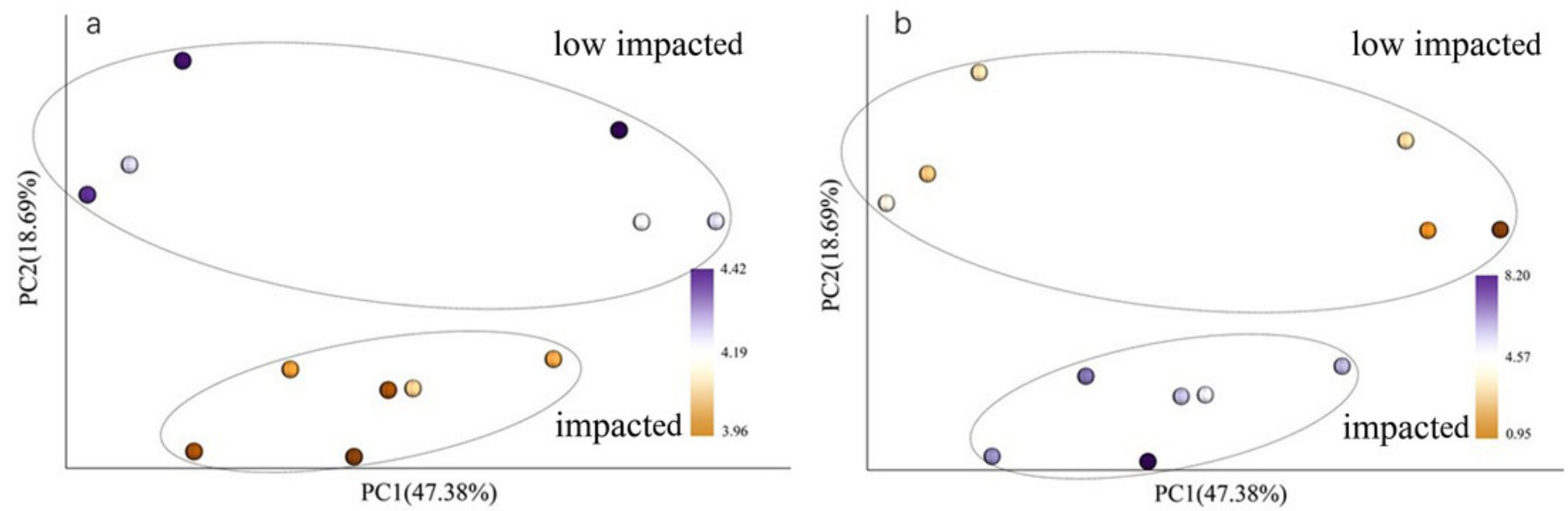


\section{Figure 4}

Relative abundance of bacterial phyla (three samples including in each treatments)

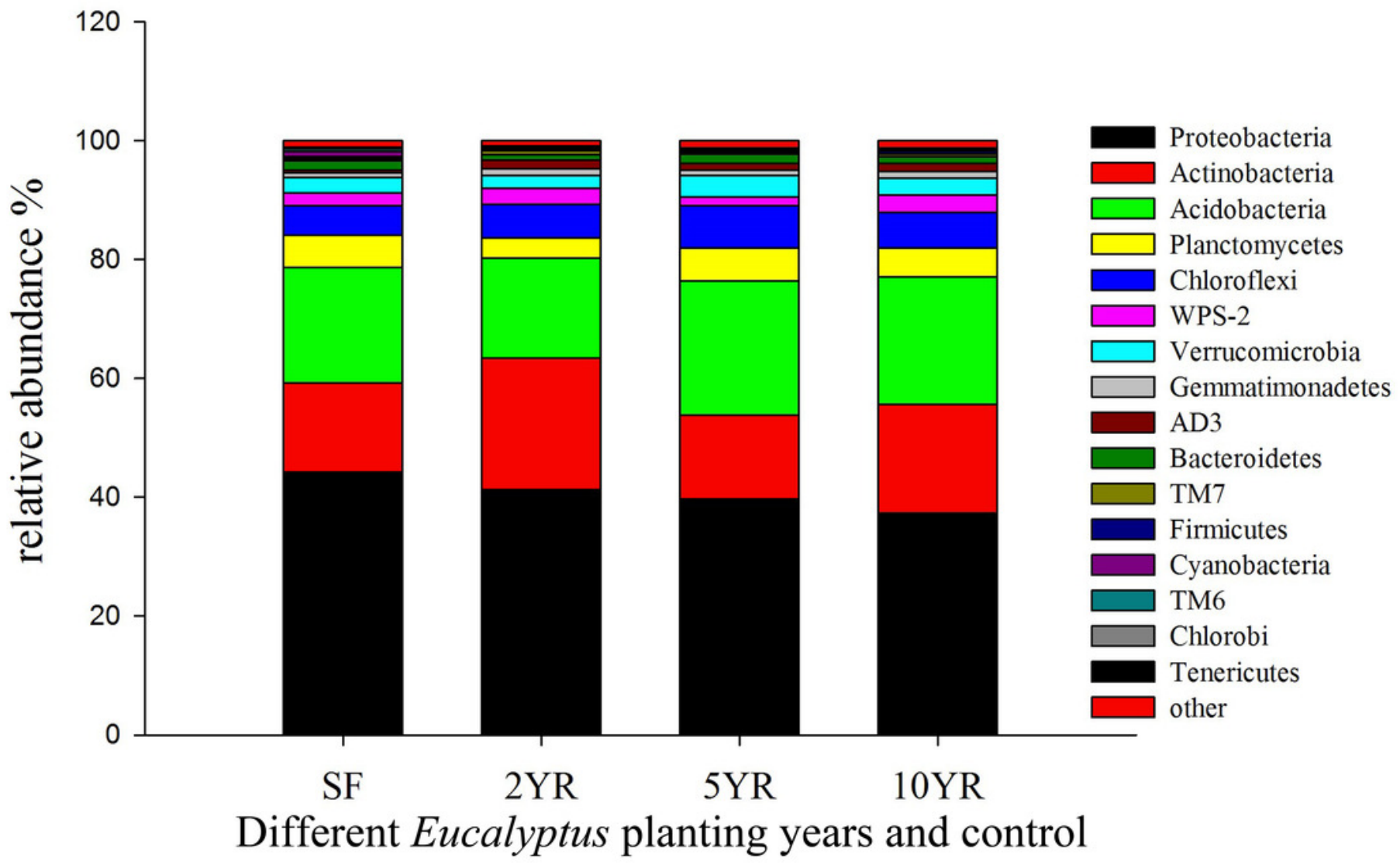


Figure 5

Differently abundant taxa abundance shown within phylogenetic lineages (LEfSe analysis) between impacted (comprised by 2 YR and 10YR) and low impacted (comprised by $5 Y R$ and SF) clusters.

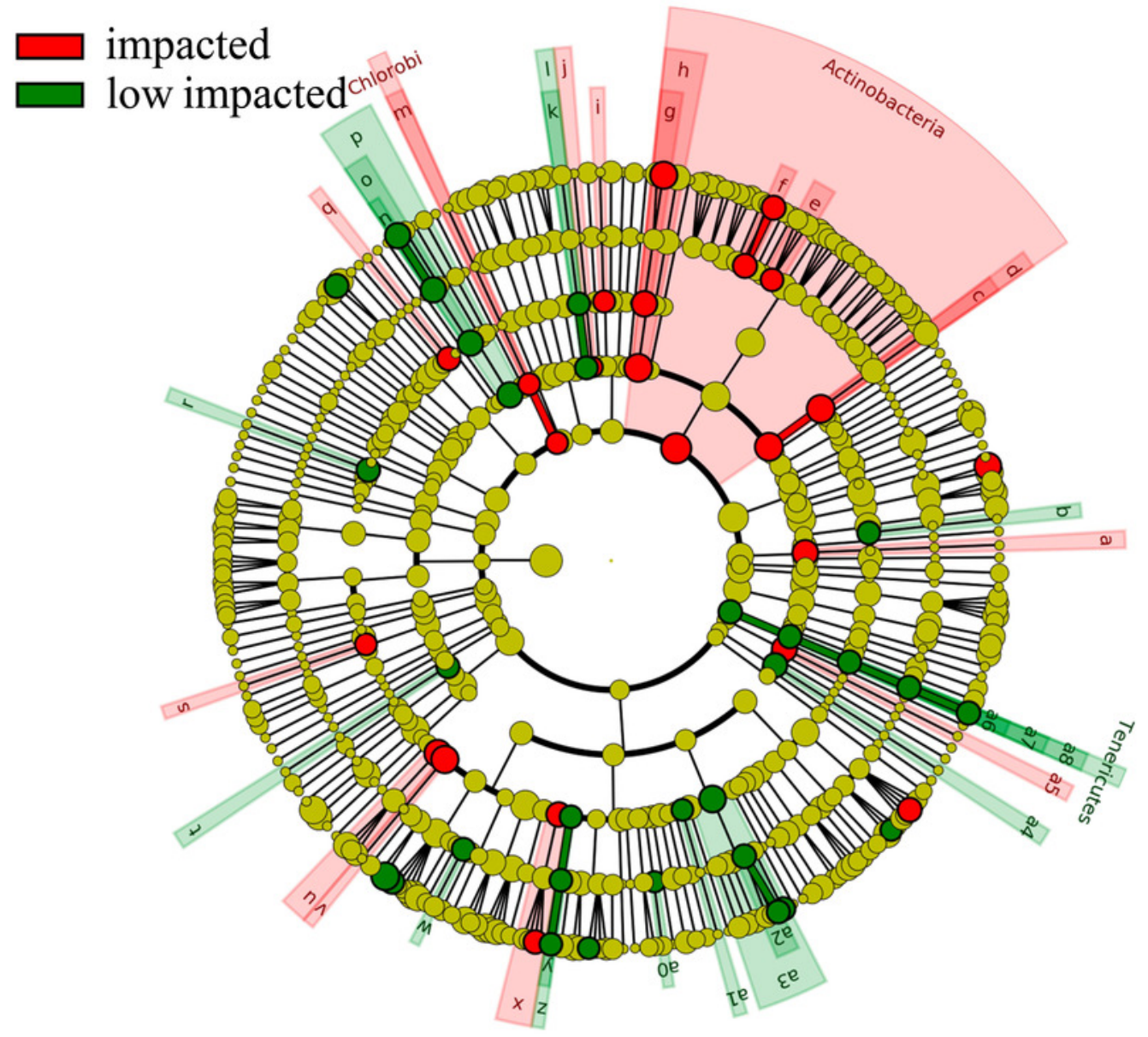

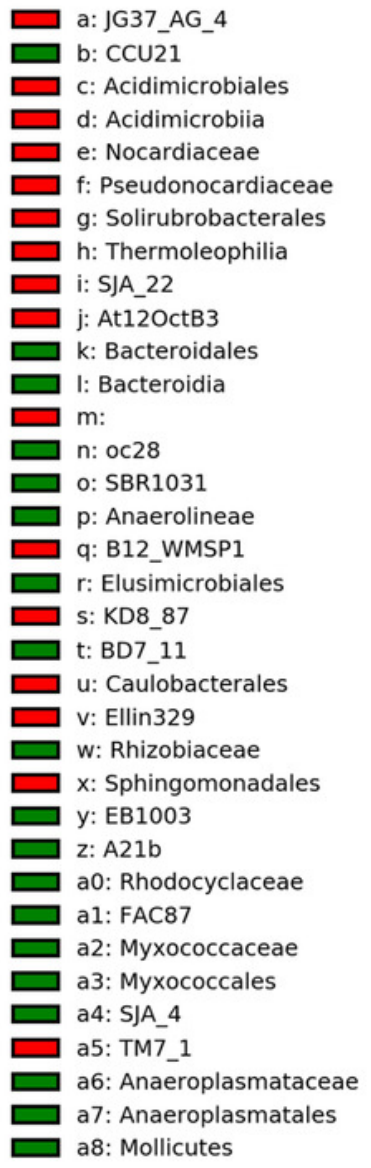


Figure 6

Canonical Correlation Analysis (CCA) of the abundance of sOTUs in bacterial community and soil environmental variables of the Eucalyptus and secondary forest.

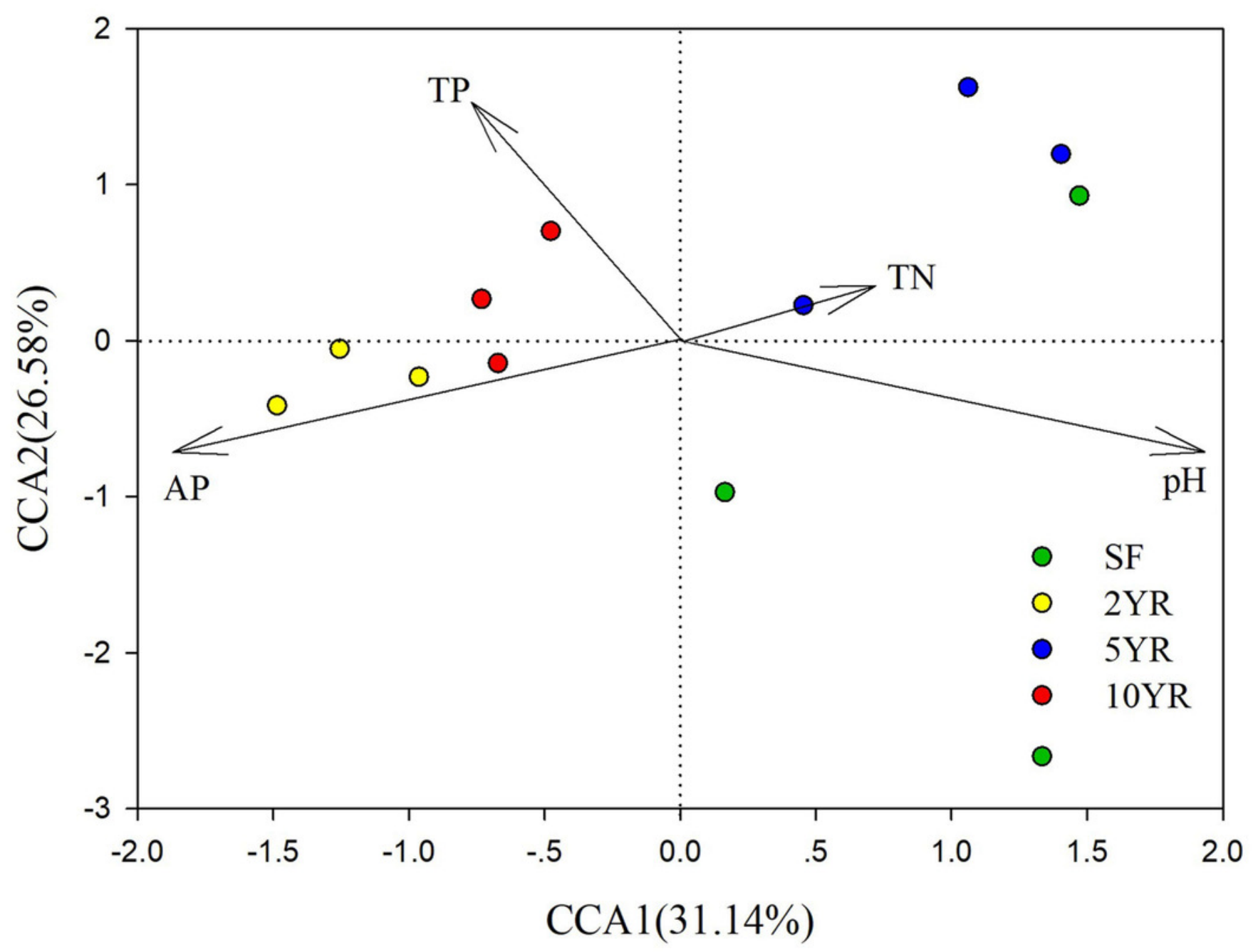




\section{Figure 7}

Relative abundance of predicted soil bacterial functions in impacted and low impacted clusters predicted by PICRUSt using KEGG Orthologs. Pathways presented here are relevant to soil ecosystem function and compound degradation, full data supplied in Table

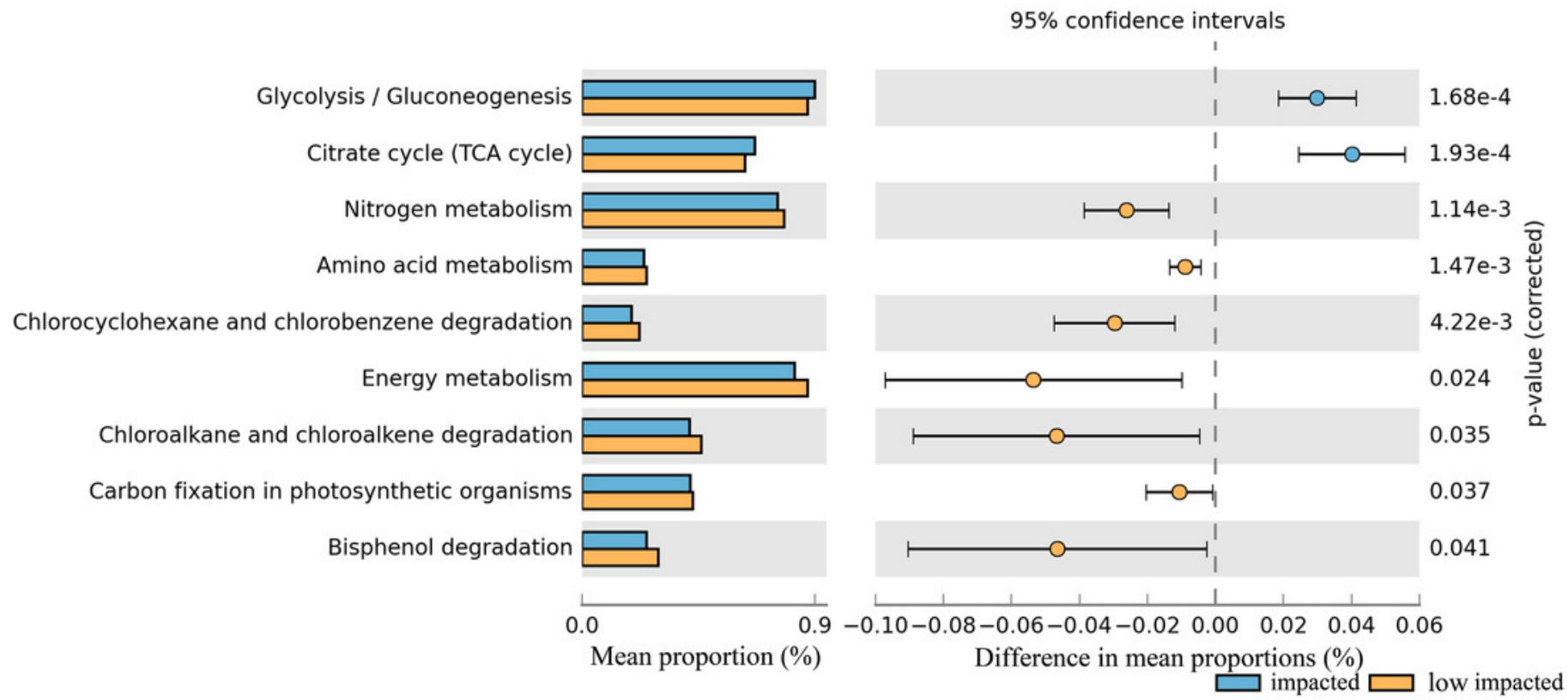




\section{Table $\mathbf{1}$ (on next page)}

Physicochemical properties in Eucalyptus plantations of different age and secondary forest

Note: different letters in rows indicate significant difference between the samples at $P<$ $0.05, n=3$. 
2

\begin{tabular}{|c|c|c|c|c|c|c|c|c|c|c|}
\hline Sample & $\mathrm{pH}$ & $\begin{array}{l}\text { SOC } \\
(\mathrm{g} / \mathrm{kg}) \\
\end{array}$ & $\begin{array}{l}\mathrm{TN} \\
(\mathrm{g} / \mathrm{kg}) \\
\end{array}$ & $\begin{array}{l}\text { TP } \\
(\mathrm{g} / \mathrm{kg}) \\
\end{array}$ & $\begin{array}{l}\text { TK } \\
(\mathrm{g} / \mathrm{kg}) \\
\end{array}$ & $\begin{array}{l}\mathrm{AN} \\
(\mathrm{mg} / \mathrm{kg})\end{array}$ & $\begin{array}{l}\mathrm{NH} 4 \\
(\mathrm{mg} / \mathrm{kg})\end{array}$ & $\begin{array}{l}\text { NO3 } \\
(\mathrm{mg} / \mathrm{kg}) \\
\end{array}$ & $\begin{array}{l}\text { AP } \\
(\mathrm{mg} / \mathrm{kg})\end{array}$ & $\begin{array}{l}\mathrm{AK} \\
(\mathrm{mg} / \mathrm{kg})\end{array}$ \\
\hline SF & $4.34 \pm 0.09 \mathrm{a}$ & $60.32 \pm 12.05 \mathrm{a}$ & $2.14 \pm 0.62 \mathrm{a}$ & $0.22 \pm 0.03 \mathrm{c}$ & $13.8 \pm 1.77 \mathrm{ab}$ & $150.28 \pm 43 \mathrm{a}$ & $21.82 \pm 2.64 b$ & $7.32 \pm 1.59 b$ & $2.98 \pm 1.78 b$ & $100.32 \pm 57.11 \mathrm{a}$ \\
\hline $2 \mathrm{YR}$ & $4.01 \pm 0.06 \mathrm{~b}$ & $50.57 \pm 6.4 b$ & $1.74 \pm 0.04 \mathrm{a}$ & $0.27 \pm 0.01 \mathrm{~b}$ & $11.67 \pm 2.04 \mathrm{~b}$ & $143.22 \pm 2.94 \mathrm{a}$ & $15.87 \pm 3.81 \mathrm{c}$ & $22.73 \pm 9.45 a$ & $7.17 \pm 0.91 \mathrm{a}$ & $63.83 \pm 7.14 \mathrm{a}$ \\
\hline $5 \mathrm{YR}$ & $4.29 \pm 0.12 \mathrm{a}$ & $61.92 \pm 2.47 \mathrm{a}$ & $2.15 \pm 0.13 \mathrm{a}$ & $0.32 \pm 0.01 \mathrm{a}$ & $8.2 \pm 0.42 \mathrm{c}$ & $164.58 \pm 25.23 \mathrm{a}$ & $32.8 \pm 2.98 \mathrm{a}$ & $10.37 \pm 4.68 \mathrm{ab}$ & $3.15 \pm 0.59 b$ & $55.51 \pm 11.63 \mathrm{a}$ \\
\hline $10 \mathrm{YR}$ & $4.06 \pm 0.07 \mathrm{~b}$ & $42.41 \pm 6.16 b$ & $1.58 \pm 0.16 \mathrm{a}$ & $0.32 \pm 0 \mathrm{a}$ & $15.08 \pm 0.52 \mathrm{a}$ & $133.12 \pm 19.52 \mathrm{a}$ & $8.85 \pm 2.35 \mathrm{~d}$ & $21.21 \pm 8.51 \mathrm{a}$ & $5.62 \pm 0.54 \mathrm{a}$ & $91.63 \pm 6.39 a$ \\
\hline
\end{tabular}




\section{Table 2 (on next page)}

Results of mantel test between different soil properties and community composition. Note: " $r$ " is symbol for Spearman rho. 


\begin{tabular}{|c|c|c|}
\hline Soil properties & $r$ & $P$-value \\
\hline $\mathrm{pH}$ & 0.328 & 0.025 \\
\hline $\mathrm{TP}$ & 0.303 & 0.041 \\
\hline $\mathrm{TN}$ & 0.297 & 0.048 \\
\hline AP & 0.22 & 0.104 \\
\hline $\mathrm{NH} 4$ & 0.119 & 0.387 \\
\hline $\mathrm{NO} 3$ & 0.114 & 0.406 \\
\hline $\mathrm{AN}$ & 0.094 & 0.541 \\
\hline SOC & 0.085 & 0.556 \\
\hline AK & 0.032 & 0.863 \\
\hline TK & -0.012 & 0.913 \\
\hline
\end{tabular}




\section{Table 3(on next page)}

Differences in relative abundance of bacterial phyla in different stages of Eucalyptus plantation and secondary forest.

Note: different letters in rows indicate significant difference between the samples at $P<$ $0.05, n=3$. 


\begin{tabular}{lllll}
\hline Phylum/Treatment & $\mathrm{SF}$ & $2 \mathrm{YR}$ & $5 \mathrm{YR}$ & $10 \mathrm{YR}$ \\
\hline Proteobacteria & $44.22 \pm 10.95 \mathrm{a}$ & $41.3 \pm 2.21 \mathrm{a}$ & $39.75 \pm 8.33 \mathrm{a}$ & $37.34 \pm 1.48 \mathrm{a}$ \\
Actinobacteria & $15.04 \pm 3.63 \mathrm{~b}$ & $22.18 \pm 2.38 \mathrm{a}$ & $14.09 \pm 3.49 \mathrm{~b}$ & $18.37 \pm 4.15 \mathrm{ab}$ \\
Acidobacteria & $19.47 \pm 6.67 \mathrm{a}$ & $16.81 \pm 2.07 \mathrm{a}$ & $22.56 \pm 4.54 \mathrm{a}$ & $21.4 \pm 1.76 \mathrm{a}$ \\
Planctomycetes & $5.38 \pm 2.7 \mathrm{a}$ & $3.33 \pm 1.13 \mathrm{a}$ & $5.51 \pm 2.16 \mathrm{a}$ & $4.79 \pm 1.09 \mathrm{a}$ \\
Chloroflexi & $5.03 \pm 2.47 \mathrm{a}$ & $5.72 \pm 0.31 \mathrm{a}$ & $7.22 \pm 2.78 \mathrm{a}$ & $6.07 \pm 1.84 \mathrm{a}$ \\
WPS-2 & $2.1 \pm 0.09 \mathrm{~b}$ & $2.75 \pm 0.17 \mathrm{a}$ & $1.41 \pm 0.56 \mathrm{~b}$ & $2.9 \pm 0.28 \mathrm{a}$ \\
Verrucomicrobia & $2.64 \pm 1.69 \mathrm{a}$ & $2.09 \pm 0.96 \mathrm{a}$ & $3.6 \pm 1.86 \mathrm{a}$ & $2.87 \pm 0.16 \mathrm{a}$ \\
Gemmatimonadetes & $0.75 \pm 0.21 \mathrm{~b}$ & $1.11 \pm 0.04 \mathrm{a}$ & $0.92 \pm 0.01 \mathrm{a}$ & $1.13 \pm 0.18 \mathrm{a}$ \\
AD3 & $0.40 \pm 0.25 \mathrm{~b}$ & $1.49 \pm 0.46 \mathrm{a}$ & $1.13 \pm 0.20 \mathrm{a}$ & $1.38 \pm 0.68 \mathrm{a}$ \\
Bacteroidetes & $1.57 \pm 0.85 \mathrm{a}$ & $0.9 \pm 0.07 \mathrm{a}$ & $1.58 \pm 0.75 \mathrm{a}$ & $1.05 \pm 0.15 \mathrm{a}$ \\
TM7 & $0.39 \pm 0.1 \mathrm{~b}$ & $0.71 \pm 0.12 \mathrm{a}$ & $0.31 \pm 0.08 \mathrm{~b}$ & $0.52 \pm 0.19 \mathrm{ab}$ \\
Firmicutes & $0.33 \pm 0.17 \mathrm{a}$ & $0.2 \pm 0.08 \mathrm{a}$ & $0.21 \pm 0.1 \mathrm{a}$ & $0.44 \pm 0.23 \mathrm{a}$ \\
Cyanobacteria & $0.96 \pm 0.63 \mathrm{a}$ & $0.29 \pm 0.10 \mathrm{~b}$ & $0.23 \pm 0.12 \mathrm{~b}$ & $0.23 \pm 0.04 \mathrm{~b}$ \\
TM6 & $0.36 \pm 0.13 \mathrm{a}$ & $0.16 \pm 0.04 \mathrm{~b}$ & $0.24 \pm 0.09 \mathrm{~b}$ & $0.16 \pm 0.05 \mathrm{~b}$ \\
Chlorobi & $0.01 \pm 0.02 \mathrm{~b}$ & $0.05 \pm 0.04 \mathrm{ab}$ & $0.03 \pm 0.02 \mathrm{ab}$ & $0.07 \pm 0.03 \mathrm{a}$ \\
Tenericutes & $0.27 \pm 0.02 \mathrm{a}$ & $0.00 \pm 0.01 \mathrm{c}$ & $0.07 \pm 0.05 \mathrm{~b}$ & $0.02 \pm 0.02 \mathrm{bc}$ \\
\hline
\end{tabular}

